\begin{tabular}{|c|c|c|c|}
\hline $\begin{array}{c}\text { AL_FARABI } \\
\text { http://dergipark.gov.tr/farabi }\end{array}$ & $\begin{array}{l}\text { International Journal on Social Sciences } \\
\text { ISSN 2564-7946 }\end{array}$ & & \\
\hline Arrival Date: 14.04 .2020 Published & \multirow{2}{*}{ DOI: 10.46291/Al-Farabi.050207 } & Volume (5) & lssue (2) \\
\hline Date: $31.05 \cdot 2020$ & & Year (ju & (e 2020) \\
\hline
\end{tabular}

\title{
Sağlık Sektöründe Ağızdan Ağıza İletişimin Tüketicilerin Demografik Özelliklerine Göre İncelenmesi: Mardin İlinde Bir Araştırma
}

\author{
Investigating Word-Of-Mouth Communication According to Demographic Features \\ of Consumers in Health Sector: A Research in Mardin
}

\author{
İsmail GÜN ${ }^{1}$
}

\begin{abstract}
ÖZET
Bu çalışma kapsamında, sağlık sektörü özelinde sağlık tüketicilerince gerçekleştirilen ağızdan ağıza iletişim faaliyetlerinin tüketicilerin demografik özelliklerine göre farklılaşıp farklılaşmadığının tespit edilmesi amaçlanmıştır. $\mathrm{Bu}$ doğrultuda bir anket formu hazırlanarak, 10 Mart 2020 ile 5 Nisan 2020 tarihleri arasında Mardin ilinde yaşayan sağlık hizmetleri tüketicileri üzerinde araştırma gerçekleştirilmiştir. Sağlık tüketicilerinin sağlık hizmetlerine yönelik ağızdan ağıza iletişim tutumlarını ölçmek üzere, beş boyuttan meydana gelen ağızdan ağıza iletişim ölçeği kullanılmıştır. Araştırma neticesinde, sağlık hizmetleri tüketicilerinin ağızdan ağıza iletişim ölçeği faktörlerine vermiş oldukları yanıtların, çeşitli demografik özelliklere göre anlamlı şekilde farklılaşmakta olduğu bulgularına ulaşılmıştır.
\end{abstract}

Anahtar Kelimeler: Sağlık, Sağlık Hizmetleri, Sağlık Sektörü, Ağızdan Ağıza İletişim, Mardin.

\begin{abstract}
Within the scope of this study, it was aimed to determine whether or not word-of-mouth activities of healthcare services consumers are different according to their demographical features in health sector. In this regard, a survey questionnaire was formed, and the research was conducted between $10^{\text {th }}$ of March, 2020 and $5^{\text {th }}$ of April 2020 on healthcare services consumers living in Mardin. In order to measure word-of-mouth attitudes of healthcare services consumers towards healthcare services, word-of-mouth scale consisting of five dimensions was used. As the result of the research, the findings that the responses of healthcare services consumers for word-of-mouth scale factors are significantly different according to various demographical features, were reached.
\end{abstract}

Keywords: Health, Healthcare Services, Health Sector, Word-of-Mouth Communication, Mardin

\section{GİRIŞ}

İnsan yaşamında sağlığın vazgeçilemez ve tartışılmaz bir önemi bulunmaktadır. Bu nedenle insanoğlunun sağlıklı bir şekilde yaşamını devam ettirebilmesi adına sağlık hizmetleri ve sağlık sektörü geliştirilmiştir. Sağlık sektöründe bilgi, herkesin kolayca elde edemeyeceği bir niteliğe sahip olduğundan ve oldukça ciddi bir uzmanlık gerektirdiğinden, sağlık hizmetlerinin tüketicileri sağl1k hizmetleri sunanlar kadar bilgi birikimine sahip olamamaktadır. Bu bağlamda sağlık hizmetlerinin tüketicileri, sağlık hizmetlerine ilişkin bilgi elde etmek üzere çoğu zaman yakınlarında bulunan ve daha önceden sağlık hizmeti deneyimi yaşamış olan başkalarına danışma ihtiyacı duymaktadırlar. Bu durum, sağlık hizmetlerinde ağıdan ağıza iletişim faaliyetlerinin görülmesine sebebiyet vermektedir. Bu çalışmada da sağlık sektöründe sağlık tüketicileri tarafından gerçekleştirilen ağızdan ağıza iletişim faaliyetlerinin tüketicilerin demografik özelliklerine göre farklılaşma durumunun incelenmesi amaçlanmıştır.

\footnotetext{
${ }^{1}$ Doktora Öğrencisi, Hasan Kalyoncu Üniversitesi, gun.47@ hotmail.com, Orcid: 0000-0001-5197-9667
} 
Sağlık hizmetlerine yönelik talep genellikle acil durumlarla anlık gereksinimler doğrultusunda ortaya çıkmaktadır. Bu acil durumlar ve anlık ihtiyaçlardan dolayı sağlık sektöründe satın alma süreci de genelde kısa olmaktadır. Bu nedenle sağlık tüketicileri, aynı sağlık hizmetini daha önceden almış olanların görüşleriyle deneyimlerinden yararlanmayı kendileri bakımından güvenilir bulabilmektedir. $\mathrm{Bu}$ bağlamda çalışma kapsamında, sağlık sektöründe tüketicilerin ağızdan ağıza iletişim faaliyetlerinin demografik özelliklere göre farklılaşıp farklılaşmadığının saptanacak olması ve ağızdan ağıza iletişimin sağlık sektöründeki etkililiğinin incelenecek olması öneme sahiptir. Zira sağlık sektöründeki ağızdan ağıza iletişim faaliyetleri hususunda yapılmış olan araştırma sayısı çok fazla değildir. Bu nedenle çalışmanın hem literatüre bir katkıda bulunması hem de Mardin ili özelinde tüketicilerin görüşlerinin ölçülecek olması önem arz etmektedir.

\section{KAVRAMSAL ÇERÇEVE}

\section{Sağlık, Sağlık Hizmetleri ve Sağlık Sektörü}

İnsanoğlu tarihsel süreç içerisinde yaşamını devam ettirebilmek üzere büyük bir mücadele içerisinde bulunmuş ve böylece öncelikle sağlıklı olmaları gerektiğini fark etmiştir. Bu doğrultuda bir toplumda mutluluk ve refahın elde edilebilmesi noktasında, toplumların birincil hedeflerinin sağliklı olmak şeklinde ifade edilmesi mümkündür (Özuysal, 2011). Sağlık kavramı, geleneksel bir tabirle hastalık halinden uzak olma şeklinde betimlenebilir (Akdur, 2003). Zira sağlıklı bir toplumun temeli, sağlıklı fertler olup, fertlerin sahibi bulundukları en önemli şeylerden birisi, refahlarıyla mutluluklarının ön şartı olan sağlıktır (Bodur, 1991). Dünya Sağlık Örgütü ise 1948'de ilan ettiği kuruluş metninde sağlık kavramını, fertlerin hayatlarını idame ettirmeleri, vücutlarının bütünlügünü koruyabilmeleri ve yaşamlarını bir ağrı, kısıtlılık veya herhangi bir sorun olmaksızın sürdürebilmeleri bağlamında açıklamıştır (WHO, 2011). Sağl1k, ülkelerin gelişmişlik seviyelerinin belirlenmesi bakımından önemli bir gösterge ve kriter olup, toplumların yaşam düzeylerinin yükseltilmesi bağlamında bir yatırım alanıdır ve ülke ekonomilerinin önem arz eden bir parçası, büyük bir hizmet sektörüdür (KılıçÖztürk, 2006).

Sağlıklı bir toplumun oluşturulması hedefine yönelmiş olan bilinçli ve insanı önemseyen bütün ülkelerde sağlık sektörüne oldukça büyük yatırımlarda bulunulmaktadır (Sarvan, 1995). Farklılık arz eden gelişmişlik düzeyleri bulunmasına karşın, dünyada yer alan bütün toplumlar sağl1k ile sağllk hizmetleri konularını daha çok önemsemeye başlamış olup, sağlık hizmetlerinin temel özelliklerinden ötürü fertlerin yaşamlarıyla doğrudan ve kuvvetli bir ilişkisi bulunduğu söylenebilir. Önceleri sağlık hizmetleri çerçevesinde sadece hekimlerle hemşirelerin dahil olduğu süreçlerden bahsedilirken, günümüz koşullarında artık muhtelif meslek dallarını da içermekte olan bir sağlık hizmetleri dönemi söz konusudur (Ersöz, 2008).

Sağlık hizmetleri; fertlerden başlayıp bütün toplumun sağlığının iyileştirilmesi ve toplumdaki genel sağlıklı durumun devamlılığının sağlanması hususunda üretilen hizmetlerin bütününü kapsamakta olup, dünya üzerinde yer alan ülkelerde en fazla önem verilmekte olan politikaların arasında yer almaktadır (Altay, 2007). Sağlık hizmetleri sağlığın muhafaza edilmesi, geliştirilmesi, hastaların tedavi edilmesi ve engelli fertlerin rehabilite edilmeleri hedefiyle verilmekte olan hizmetlerin tümüdür (Tengilimoğlu vd., 2017). Sağlık hizmetleri, fertlerle bu fertlerin oluşturdukları toplumların varlıklarının fiziksel, ruhsal ve sosyal bakımdan belli bir dengenin içinde devam ettirilebilmesi hususunda sunulması gerekli olan hizmetlerden meydana gelmektedir (Mutlu-Işık, 2012).

Sağlık hizmetleri temel olarak koruyucu sağlık hizmetleri, tedavi edici sağl1k hizmetleri, rehabilitasyon hizmetleri ve sağlı̆̆ geliştirici sağlı hizmetleri şeklinde dört başlık altında değerlendirilmektedir (Somunoğlu, 2012). Koruyucu sağlık hizmetleri, bulaşıcı hastalıkların fertler arasında geçişini önlemek üzere gerçekleştirilen sağlı hizmetlerine verilen isimdir. Bu çerçevede verilen hizmetlerle beraber, çevresel önlemler alınarak toplumda genel sağlık durumunun muhafaza edilmesi hedeflenmektedir (Kurtulmuş, 1998). Tedavi edici sağlık hizmetleri, fertlerin kaybolan sağlıklarının eski durumuna geri getirilmesi, hastalıklara sebebiyet veren faktörlerin ortadan 
kaldırılması, sakatlıklarının iyileştirilmesi hususunda sunulan sağlık hizmetlerine verilen isimdir (Somunoğlu, 2012). Tedavi edici sağlık hizmetleri üç basamaktan meydana gelmektedir. Birinci basamakta başvuru ve ayakta tedavi süreci, ikinci basamakta yatarak gerçekleştirilmekte olan tedavi hizmetleri, üçüncü basamakta gelişmiş teknolojiden faydalanılan tedavi hizmetleri sunulmaktadır (Altay, 2007). Rehabilitasyon hizmetleri, fertlerin fiziksel veya ruhsal açıdan yaşamakta oldukları problemlerin neticesinde beliren muhtelif kalıcı durumların sonucu olarak çevrelerindeki insanlara bağımlı biçimde yaşamlarını idame ettirme zorunluluğu içerisinde kalmamaları maksadıyla gerçekleştirilen sağlık hizmetlerine verilen isimdir (Ateş-Kırılmaz, 2013). Sağlığı geliştirici sağlık hizmetleri, sağlık sistemi çerçevesinde bütünsel bir iyileşmenin elde edilmesi, toplum genelinin daha sağlıklı bir şekilde yaşamını idame ettirmesi maksadıyla gereken çalışmaların gerçekleştirilmesi, sağlığa ilişkin gerekli siyasi ve sosyal dönüşümlerin sağlanması hususunda yürütülen sağlık hizmetlerine verilen isimdir (Kavuncubaşı-Yıldırım, 2010).

\section{Sağlık Sektöründe Ağızdan Ağıza İletişim}

Ağızdan ağıza iletişim, bir mal, hizmet veya firmaya ilişkin ticari açıdan algılanmayan, bir göndericiyle bir alıcının arasında gerçekleşen informal, bireyden bireye iletişim şeklinde ifade edilebilir (Wangenheim, 2005). Ağızdan ağıza iletişim, bir marka ya da işletmeye ilişkin bir düşünce ve/veya bilginin bir fertten diğerine muhtelif iletişim tekniklerinin aracılığıyla iletilmesidir (Kozinets vd., 2010). Ağızdan ağıza iletişim yüz yüze, interaktif, geçici, spontane olması ve ses veya sözlerin muhtelif biçimlerde ifade edilmemesiyle reklamdan ayrışmaktadır (Stern, 1994).

Ağızdan ağıza iletişim; fertlerin deneyimlerinin sonucu olarak yüz yüze görüşmeler gerçekleştirerek, telefon ile veya internet ortamı üzerinde edindikleri deneyimlerin neticesinde diğerlerine bu deneyimlerini aktarmak suretiyle o fertlerin satın alma kararlarını etkileyebilmektir. Fertler bir hizmetle ilintili olarak satın alma safhasındayken, etraflarındaki aile bireyleri, yakın arkadaşları veya çevrelerindeki başka fertlerden satın alacakları şeylere ilişkin bilgi edinme çabası içindedirler. Bu doğrultuda, ağızdan ağıza iletişimin diğer iletişim türleri kıyasla güvenilirlik, deneyim aktarımı, müşteriye dayalı olma, zaman ve para tasarrufu gibi önemli ayırt edici özellikleri bulunmaktadır (Karaca, 2010). Silverman (2007) ise ağızdan ağıza iletişimin 12 özelliğinden bahsetmiştir. Buna göre ağızdan ağıza iletişim, piyasada bulunan en nüfuzlu, etkin ve inandırıcı güç olup, bir deneyim ve iletim mekanizmasıdır. A ğızdan ağıza iletişim, bağımsız olup, bu nedenle güvenilirdir ve ürünün bir parçası niteliğine sahiptir. Kişiye özel olan ağızdan ağıza iletişim; kendi kendine oluşmakta, kendi kendini beslemekte, katlanarak hatta bazen patlama yapmak suretiyle çoğalmaktadır. Hız ve hareket serbestliği noktasında sınırsız olup, tek bir kaynak ya da nispeten küçük olan kaynaklardan çıkabilmektedir, ancak kaynağın özelliğine son derece bağlı durumdadır. Ağızdan ağıza iletişim, büyük ölçüde zaman ve iş tasarrufu sağlamaktadır ve teşvik edilip güçlendirilmesi, sürdürülmesi oldukça ucuz olabilmektedir. Son olarak, genellikle negatif ağızdan ağıza iletişim ön planda olsa dahi, ortaya koymakta olduğu etkilerinden ötürü pozitif kabul edilebilmektedir.

Ağızdan ağıza iletişim, pozitif ağızdan ağıza iletişim ve negatif ağızdan ağıza iletişim şeklinde ikiye ayrılmaktadır. Pozitif ağızdan ağıza iletişim, tüketicilere arzı yapılan malın veya hizmetin kalitesinin, tüketicilerce oldukça değerli bulunmasıyla ilişkilidir (Derbaix-Vanhamme, 2003). Bu doğrultuda pozitif ağızdan ağıza iletişim, işletmelerin ürünleriyle hizmetlerini teşvik etmek üzere faydalanmakta oldukları önem arz eden bir araç niteliğindedir (Gremler vd., 2001). Bir hizmetten faydalanan tüketiciler, satın almış oldukları ürün ya da hizmetle ilgili olarak hayal kırıklığı yaşamaları durumunda, karşılaştıkları negatif durumun işletme tarafınca karşılanmaması halinde, o işletmeyi cezalandırmak üzere negatif ağızdan ağıza iletişim aktivitelerinde bulunmaktadırlar. Bu bağlamda negatif ağızdan ağıza iletişim, negatif değere sahip, resmi olmayan tarafların arasında ürünler ya da hizmetlere ilişkin olarak gerçekleşmekte olan değerlendirme ve iletişim sürecine verilen isimdir (Çelikkan, 2009). Başka bir ifadeyle negatif ağızdan ağıza iletişim, tüketicilerin önemli bir bölümünün memnuniyetsizlik durumlarını çevrelerinde yer alan diğer insanlara iletmeleri ile ortaya çıkmaktadır (Kitapçı, 2008). 
Bir hizmet hususunda satın alma kararı verilirken tüketicilerin çoğunlukla muhtelif bilgi kaynaklarına başvurmakta oldukları görülmektedir. Sağlık hizmeti genel olarak bir zorunluluk nedeniyle ortaya çıktığı ve tüketicilerin de genellikle sağlık ve sağlık hizmetleri konularında sınırlı bilgileri olduğundan, bu noktada ağızdan ağıza iletişim faaliyetleri büyük bir önem kazanmaktadır (Yılmaz, 2011). Zira sağlık sektöründe bilgi anlaşılması zor ve öznel olmakla birlikte, sağlıkla ilgili karşılaşılabilecek riskler de yüksek düzeyde olabilmektedir (Öz ve Uyar, 2014). Sağlık hizmetleri, fertlerin gündelik yaşamlarını derin şekilde etkilemekte olan ve pahalı sayılabilecek bir hizmet olduğundan, sağlık hizmetlerin kullanılmasını etkileyen bütün unsurların anlaşılması son derece oldukça önemlidir. Bu unsurlardan birisi olan ağızdan ağıza iletişim, fertlerin sağlık davranışları üzerinde ciddi bir etkiye sahip durumdadır (Martin, 2016). Bir sağlık kurumu veya hekim hususunda fertlerin vermekte oldukları referanslar, aktarmakta oldukları tecrübeler, diğer sağlık tüketicilerinin sağlık kurumu ve hekime ilişkin olarak bir tercihte bulunmaları noktasında etkiye sahip olmakla birlikte, onlara sunulmakta olan hizmete yönelik olarak da bir fikir vermektedir. Bu bağlamda, sağlik hizmeti sunumunda bulunan kurumlar açısından sunumu yapılan hizmetlerle ilintili pozitif bir imajın yaratılması ve özellikle bu sağlık hizmetlerinden daha önceden yararlanmış olan kişilerce, hizmetten henüz yararlanmamış olan potansiyel sağlık tüketicilerine pozitif tavsiyelerde bulunulması son derece önemlidir (Y1lmaz, 2011).

\section{Önceki Çalışmalar}

Sağlık sektörü çerçevesinde ağızdan ağıza iletişimin tüketicilerin demografik özelliklerine göre farklılaşıp farklılaşmadığının incelenmesi hususunda literatürde gerçekleştirilmiş olan çeşitli çalışmalar bulunmaktadır. Usta ve Tengilimoğlu (2000) tarafından yapılan çalışmada, sağlık hizmetleri kapsamında faydalanılan reklamlarla sağlık hizmetleri tüketicilerin bu reklamlara yönelik tutumları incelenmiş olup, sağlık hizmetleri tüketicilerinin sağlık hizmetlerine ilişkin olarak faydalandıkları bilgi kaynakları arasında arkadaşlarla akrabaların tavsiyelerinin \%28,3'lük bir orana sahip olduğu görülmüştür. Kılıçer (2006) tarafınca gerçekleştirilen araştırmada, tüketicilerin satın alma kararlarında ağızdan ağıza iletişimin etkisi incelenmiş; araştırma sonucunda sağlık hizmetleri tüketicilerinin sağlık hizmeti satın alma kararlarında ağızdan ağıza iletişimden yüksek düzeyde etkilendikleri tespit edilirken; ağızdan ağıza iletişimin etkisinin cinsiyet, medeni durum ve yaş grubuna göre anlamlı farklılık göstermediği bulguları elde edilmiştir. Öz (2016) tarafınca yapılan araştırmada ağızdan ağıza iletişimin sağlık pazarlamasında satın alma kararı üzerindeki etkisi incelenmiş, araştırmanın sonucunda sağlık hizmetleri pazarlaması kapsamında ağızdan ağıza iletişimin tüketicilerin satın alma kararlarının üzerinde etkiye sahip olduğu bulgusuna rastlanmıştır. Orak (2018) tarafından yapılan çalışmada, sağlık hizmetleri pazarlamasında tüketicilerin demografik verilerine göre ağızdan ağıza iletişimin etkililiği incelenmiş olup; araştırma sonucunda cinsiyete ve eğitim durumuna göre ağızdan ağıza iletişim faaliyetlerinde anlamlı farklılık saptanırken; yaş grubu ve medeni duruma göre hiçbir faktörde anlamlı farklılığa rastlanmamıştır. Gürcü (2018) tarafından yapılan çalışmada, ağızdan ağıza iletişimin sağlık hizmetleri pazarlamasındaki önemi ve tüketicilerin sağlık hizmeti kullanım tercihi üzerindeki etkisi incelenmiş; araştırma neticesinde cinsiyete, medeni duruma, yaş grubuna ve aylık gelire göre ağızdan ağıza iletişim faaliyetlerinde anlamlı farklılık saptanırken; eğitim durumuna göre herhangi bir faktörde anlamlı farklılık tespit edilmemiştir. Ayaydın (2019) tarafından yapılan araştırmada, ağızdan ağıza pazarlama iletişiminin sağlık hizmetlerinden yararlanan tüketicilerin satın alma kararına etkisi incelenmiş; araştırma sonucunda cinsiyete, gelir durumuna ve eğitim durumuna göre ağızdan ağıza iletişim faaliyetlerinde anlamlı farklılık saptanırken; yaş grubuna ve medeni duruma göre herhangi bir faktörde anlamlı farklılık tespit edilmemiştir. 


\section{ARAŞTIRMA YÖNTEMI}

\section{Araştırmanın Evreni ve Örneklemi}

Araştırmanın evrenini, Türkiye'deki sağlık hizmetleri tüketicileri oluşturmaktadır. Örneklem olarak Mardin ilindeki sağlık hizmetleri tüketicileri seçilmiştir. Bu ilin seçilmesinde, araştırmacının bu ilde ikamet ediyor ve çalışıyor olması etkili olmuştur. Kolayda örnekleme tekniği ile Mardin ilindeki sağlık hizmetleri tüketicileri üzerinde, aşağıda detayları yer alan anket formu uygulanmıştır. Anket uygulaması, 10 Mart 2020 ile 5 Nisan 2020 arasında gerçekleştirilmiştir.

Ankete 235 kişi katılım göstermiştir. Cinsiyet açısından katılımcıların 115'i $(\% 48,9)$ kadın, 120'si (\%51,1) erkektir. Medeni durum bakımından 87 (\%37,0) kişi bekar, $116(\% 49,4)$ kişi evli olup, 32 $(\% 13,6)$ kişi diğer seçeneğini işaretlemiştir. Yaş gruplarına göre, $67(\% 28,5)$ kişi 18-25 yaş grubunda, $44(\% 18,7)$ kişi 26-34 yaş grubunda, $64(\% 27,2)$ kişi 35-44 yaş grubunda, $60(\% 25,5)$ kişi 45 ve üzeri yaş grubundadır. Eğitim düzeyi açısından $74(\% 31,5)$ kişi lise, $48(\% 20,4)$ kişi önlisans, $76(\% 32,3)$ kişi lisans, $37(\% 15,7)$ kişi lisansüstü mezunudur. Aylık hanehalkı gelir durumu bakımından 67 $(\% 28,5)$ kişi 2.500 TL'den az, $62(\% 26,4)$ kişi 2.500 TL-5.000 TL arasında, 50 (\%21,3) kişi 5.001 TL-7.500 TL arasında, $56(\% 23,8)$ kişi 7.500 TL'den fazla aylık hanehalkı gelirine sahiptir. Çalışma durumuna göre, $163(\% 69,4)$ kişi bir işte çalışmakta, $72(\% 30,6)$ kişi bir işte çalışmamaktadır.

\section{Araştırma Modeli, Değişkenler ve Hipotezler}

Şekil 1'de çalışma kapsamında oluşturulan araştırma modeli yansıtılmıştır. Model çerçevesinde bu araştırmanın değişkenleri şu şekildedir:

i. Bă̆ımlı Değişken: Ağızdan Ağıza İletişim

a. Bilgi Alınan Kişinin Uzmanlık Düzeyi

b. Bilgi Alınan Kişi ile Yakınlık Derecesi

c. Hizmetle İlgili Uzmanlık Düzeyi

d. Algılanan Risk Düzeyi

e. Ağızdan Ağıza İletişimin Etki Düzeyi

ii. Kontrol Değişkenleri: Demografik Özellikler (Cinsiyet, yaş, eğitim düzeyi, medeni durum, aylık hanehalkı gelir durumu, çalışma durumu)

iii.

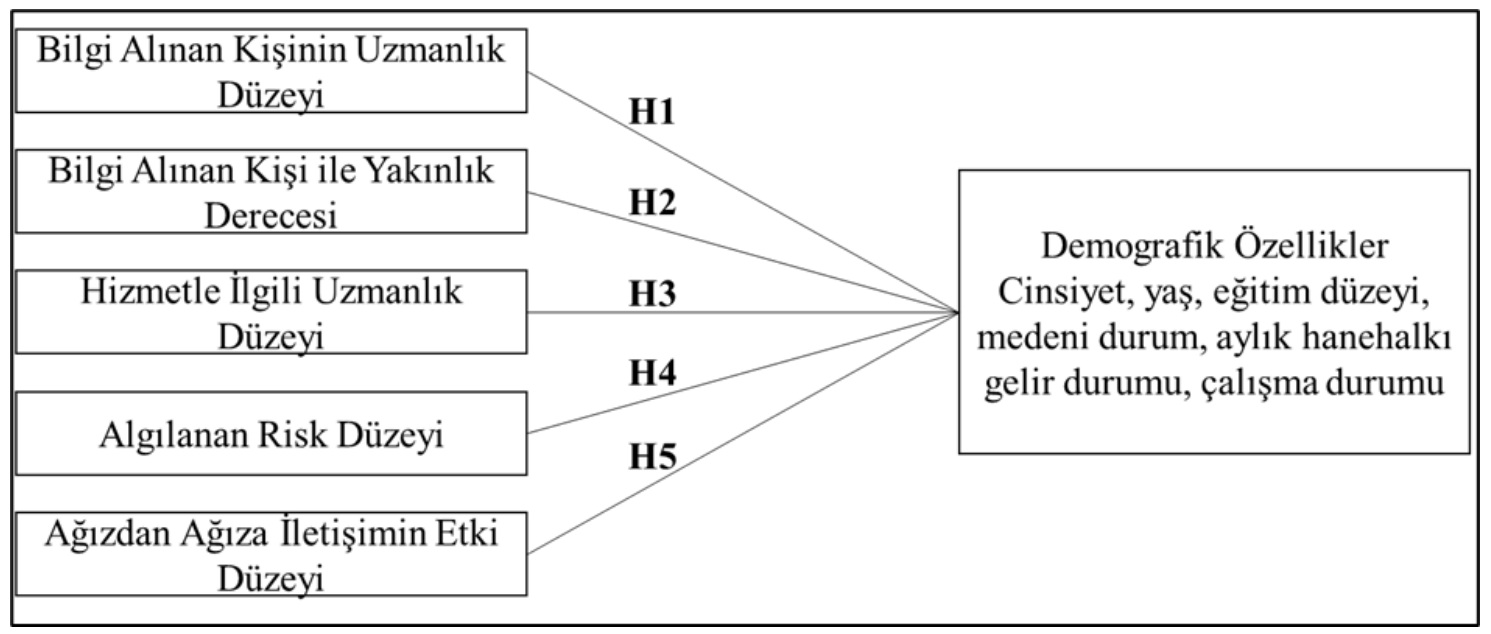




\section{Şekil 1. Araştırma Modeli}

Yukarıda yer alan araştırma modeli çerçevesinde, araştırmanın ana ve alt hipotezleri şu şekilde belirlenmiştir:

$\mathrm{H} 1$ = Bilgi alınan kişinin uzmanlık düzeyine verilen yanıtlar, demografik özelliklere göre farklılaşmaktadır.

- H1a = Bilgi alınan kişinin uzmanlık düzeyine verilen yanıtlar, cinsiyete göre farklılaşmaktadır.

- $\mathrm{H} 1 \mathrm{~b}=$ Bilgi alınan kişinin uzmanlık düzeyine verilen yanıtlar, yaş grubuna göre farklılaşmaktadır.

- H1c = Bilgi alınan kişinin uzmanlık düzeyine verilen yanıtlar, eğitim düzeyine göre farklılaşmaktadır.

- H1d = Bilgi alınan kişinin uzmanlık düzeyine verilen yanıtlar, medeni duruma göre farklılaşmaktadır.

- H1e = Bilgi alınan kişinin uzmanlık düzeyine verilen yanıtlar, aylık hanehalkı gelir durumuna göre farklılaşmaktadır.

- H1f = Bilgi alınan kişinin uzmanlık düzeyine verilen yanıtlar, çalışma durumuna göre farklılaşmaktadır.

$\mathrm{H} 2$ = Bilgi alınan kişi ile yakınlık derecesine verilen yanıtlar, demografik özelliklere göre farklılaşmaktadır.

- $\mathrm{H} 2 \mathrm{a}=$ Bilgi alınan kişi ile yakınlık derecesine verilen yanıtlar, cinsiyete göre farklılaşmaktadır.

- $\mathrm{H} 2 \mathrm{~b}=$ Bilgi alınan kişi ile yakınlık derecesine verilen yanıtlar, yaş grubuna göre farklılaşmaktadır.

- $\mathrm{H} 2 \mathrm{c}=$ Bilgi alınan kişi ile yakınlık derecesine verilen yanıtlar, eğitim düzeyine göre farklılaşmaktadır.

- $\mathrm{H} 2 \mathrm{~d}=$ Bilgi alınan kişi ile yakınlık derecesine verilen yanıtlar, medeni duruma göre farklılaşmaktadır.

- $\mathrm{H} 2 \mathrm{e}=$ Bilgi alınan kişi ile yakınlık derecesine verilen yanıtlar, aylık hanehalkı gelir durumuna göre farklılaşmaktadır.

- $\mathrm{H} 2 \mathrm{f}=$ Bilgi alınan kişi ile yakınlık derecesine verilen yanıtlar, çalışma durumuna göre farklılaşmaktadır.

$\mathrm{H} 3$ = Hizmetle ilgili uzmanlık düzeyine verilen yanıtlar, demografik özelliklere göre farklılaşmaktadır.

- $\mathrm{H3a}=$ Hizmetle ilgili uzmanlık düzeyine verilen yanıtlar, cinsiyete göre farklılaşmaktadır.

- $\mathrm{H} 3 \mathrm{~b}=$ Hizmetle ilgili uzmanlık düzeyine verilen yanıtlar, yaş grubuna göre farklılaşmaktadır.

- $\mathrm{H} 3 \mathrm{c}=$ Hizmetle ilgili uzmanlık düzeyine verilen yanıtlar, eğitim düzeyine göre farklılaşmaktadır.

- $\mathrm{H} 3 \mathrm{~d}=$ Hizmetle ilgili uzmanlık düzeyine verilen yanıtlar, medeni duruma göre farklılaşmaktadır.

- $\mathrm{H} 3 \mathrm{e}=$ Hizmetle ilgili uzmanlık düzeyine verilen yanıtlar, aylık hanehalkı gelir durumuna göre farklılaşmaktadır. 
- H3f = Hizmetle ilgili uzmanlık düzeyine verilen yanıtlar, çalışma durumuna göre farklılaşmaktadır.

H4 = Algılanan risk düzeyine verilen yanıtlar, demografik özelliklere göre farklılaşmaktadır.

- $\mathrm{H} 4 \mathrm{a}=$ Algılanan risk düzeyine verilen yanıtlar, cinsiyete göre farklılaşmaktadır.

- $\mathrm{H} 4 \mathrm{~b}=$ Algılanan risk düzeyine verilen yanıtlar, yaş grubuna göre farklılaşmaktadır.

- $\mathrm{H} 4 \mathrm{c}=$ Algılanan risk düzeyine verilen yanıtlar, eğitim düzeyine göre farklılaşmaktadır.

- $\mathrm{H} 4 \mathrm{~d}=$ Algilanan risk düzeyine verilen yanıtlar, medeni duruma göre farklılaşmaktadır.

- $\mathrm{H} 4 \mathrm{e}=$ Algılanan risk düzeyine verilen yanıtlar, aylık hanehalkı gelir durumuna göre farklılaşmaktadır.

- $\mathrm{H} 4 \mathrm{f}=$ Algılanan risk düzeyine verilen yanıtlar, çalışma durumuna göre farklılaşmaktadır.

H5 = Ağızdan ağıza iletişimin etki düzeyine verilen yanıtlar, demografik özelliklere göre farklılaşmaktadır.

- H5a = Ağızdan ağıza iletişimin etki düzeyine verilen yanıtlar, cinsiyete göre farklılaşmaktadır.

- $\mathrm{H} 5 \mathrm{~b}=$ Ağızdan ağıza iletişimin etki düzeyine verilen yanıtlar, yaş grubuna göre farklılaşmaktadır.

- $\mathrm{H} 5 \mathrm{c}=$ Ağızdan ağıza iletişimin etki düzeyine verilen yanıtlar, eğitim düzeyine göre farklılaşmaktadır.

- $\mathrm{H} 5 \mathrm{~d}=$ Ağızdan ağıza iletişimin etki düzeyine verilen yanıtlar, medeni duruma göre farklılaşmaktadır.

- $\mathrm{H} 5 \mathrm{e}=\mathrm{Ağ} 1 z d a n$ ağıza iletişimin etki düzeyine verilen yanıtlar, aylık hanehalkı gelir durumuna göre farklılaşmaktadır.

- H5f = Ağızdan ağıza iletişimin etki düzeyine verilen yanıtlar, çalışma durumuna göre farklılaşmaktadır.

\section{Verilerin Toplanması ve Analizi}

Araştırmada veri toplamak üzere, nicel veri toplama yöntemleri içerisinden anket tekniği kullanılmıştır. Hazırlanıp uygulanan anket formu iki bölümden meydana gelmektedir. Anket formunun ilk bölümünde, katılımcıların demografik özelliklerini tespit etmeye yönelik olarak cinsiyet, yaş, medeni durum, eğitim düzeyi, aylık hanehalkı gelir durumu ve çalışma durumu olmak üzere 6 soru bulunan Kişisel Bilgi Formu yer almaktadır.

Anket formunun ikinci bölümünde Ağızdan Ağıza İletişim Ölçeği kullanılmıştır. Ölçek Türkiye'de daha önce dört farklı araştırmacı (Kılıçer, 2006; Şimşek, 2009; Öz, 2016; Orak, 2018) tarafından kullanılmıştır. Beş boyuttan ve 17 maddeden meydana gelen ölçekte; bilgi alınan kişinin uzmanlık düzeyi ve bilgi alınan kişi ile müşterinin yakınlık derecesi ile ilgili ifadeler Frenzen ve Davis'in (1990) geliştirdiği ölçekten, bilgi alanın uzmanlık düzeyi ve müşterinin hizmet alırken algıladığ risklerle ilgili ifadeler Bansal ve Voyer'in (2000) geliştirdiği ölçekten, iletişimden etkilenme düzeyi ile ilgili ifadeler ise O'cass ve Grace (2004) ile Gilly vd.'nin (1998) geliştirdiği ölçekten yararlanılarak oluşturulmuştur.

Anket formu vasitasıyla elde edilen verilerin analizi hususunda SPSS 22.0 istatistik programı kullanılmıştır. Bu doğrultuda ilgili analizleri gerçekleştirmek üzere, frekans tabloları, tanımlayıcı istatistikler, faktör analizi, güvenilirlik analizi, Bağımsız Örneklem T Testi ve Tek Yönlü ANOVA Testinden faydalanılmıştır. 


\section{ARAŞTIRMA BULGULARI}

Çalışma kapsamında önceden oluşturulmuş hipotezleri test edebilmek için öncelikle araştırmada kullanılan ölçek üzerinde faktör analizi ve güvenilirlik analizi gerçekleştirilmiştir. İlgili analiz bulguları Tablo 1'de yansitılmıştır.

Tablo 1'de görüldüğü üzere, Ölçek üzerinde yapılan faktör analizi neticesinde elde edilen KMO değerine $(0,911)$ göre, araştırma kapsamında ulaşılan örneklem büyüklügü, ölçek için faktör analizi yapılması hususunda yeterlidir. Bartlett Küresellik Testi sonuçlarına göre (Ki-Kare: 2261,774; sd: 136; Sig.: 0,000) ise, ölçeğin faktör analizi yapılabilmesi hususunda uygun olduğu tespit edilmiştir. Tablo 1'de yer alan bulgulara göre, faktör analizi sonucunda 5 faktör elde edilmiş olup, elde edilen tüm faktörler orijinal ölçekler ile yapısal açıdan uyumlu durumdadır ve tüm ifadeler orijinal ölçeklerle uyumlu şekilde dağılım göstermiştir. Bu doğrultuda, elde edilen faktörler "Bilgi Alınan Kişi ile Yakınlık Derecesi (KYD)", "Bilgi Alınan Kişinin Uzmanlık Düzeyi (KUD)", "Hizmetle İlgili Uzmanlık Düzeyi (HUD)", “Algılanan Risk Düzeyi (ARD)” ve "Ağızdan Ağıza İletişimin Etki Düzeyi (AED)" şeklinde isimlendirilmiştir.

Tablo 1'de görülebildiği gibi, ölçeğin toplam açıklanan varyansı \% 73,405'tir. ARD faktörü varyansın \%16,94'ünü, KUD faktörü varyansın \%14,48'ini, KYD faktörü varyansın \%14,44'ünü, AED faktörü varyansın \%14,13'ünü, HUD faktörü varyansın \%13,41'ini açıklamaktadır. Tablo 1'de ayrıca ölçeğin ve elde edilen faktörlerin güvenilirlik analizi sonuçları da gösterilmiştir. Buna göre, ölçeğin güvenilirliği 0,923 ile oldukça yüksektir. ARD faktörünün güvenilirliği 0,837 ; KUD faktörünün güvenilirliği 0,788; KYD faktörünün güvenilirliği 0,836; AED faktörünün güvenilirliği 0,873; HUD faktörünün güvenilirliği 0,812 olarak yüksek düzeyde tespit edilmiştir.

Tablo 1. Faktör Analizi ve Güvenilirlik Analizi Bulguları

\begin{tabular}{|c|c|c|c|c|c|c|c|c|}
\hline Kod & İfade & ARD & KUD & KYD & AED & HUD & Güvenilirlik & Ölçek \\
\hline ARD3 & $\begin{array}{l}\text { Satın almadan önce bu } \\
\text { hizmetin verebileceği } \\
\text { fiziksel zarar nedeniyle } \\
\text { duyduğunuz kaygı düzeyi } \\
\text { (sağlığı olumsuz yönde } \\
\text { etkileme gibi) }\end{array}$ & 0,806 & & & & & \multirow{4}{*}{0,837} & \multirow{7}{*}{0,923} \\
\hline ARD4 & $\begin{array}{l}\text { Satın almadan önce bu } \\
\text { sağlık hizmetinin teknik } \\
\text { olarak karmaşı olmas } \\
\text { nedeniyle duyduğunuz } \\
\text { kaygı düzeyi }\end{array}$ & 0,797 & & & & & & \\
\hline ARD1 & $\begin{array}{lr}\text { Satın almadan önce bu } \\
\text { sağlık hizmetinin parasal } \\
\text { külfeti } & \text { nedeniyle } \\
\text { duyduğunuz kaygı düzeyi }\end{array}$ & 0,759 & & & & & & \\
\hline ARD2 & $\begin{array}{l}\text { Satın almadan önce bu } \\
\text { sağlık } \text { hizmetinin } \\
\text { performansı (hizmetin hızı, } \\
\text { kalitesi gibi) ile ilgili } \\
\text { duyduğunuz kaygı düzeyi }\end{array}$ & 0,749 & & & & & & \\
\hline KUD3 & $\begin{array}{l}\text { Bilgi aldığınız kişinin } \\
\text { kullanıcı olarak bu } \\
\text { hizmetle ilgili deneyimi }\end{array}$ & & 0,793 & & & & \multirow{3}{*}{0,788} & \\
\hline KUD2 & $\begin{array}{l}\text { Bilgi aldığınız kişinin bu } \\
\text { hizmetle ilgili } \\
\text { eğitim/uzmanlık düzeyi }\end{array}$ & & 0,753 & & & & & \\
\hline KUD1 & $\begin{array}{l}\text { Bilgi aldığınız kişinin satın } \\
\text { aldığınız sağlık hizmetinin }\end{array}$ & & 0,647 & & & & & \\
\hline
\end{tabular}




\section{Al-Farabi International Journal on Social Sciences}

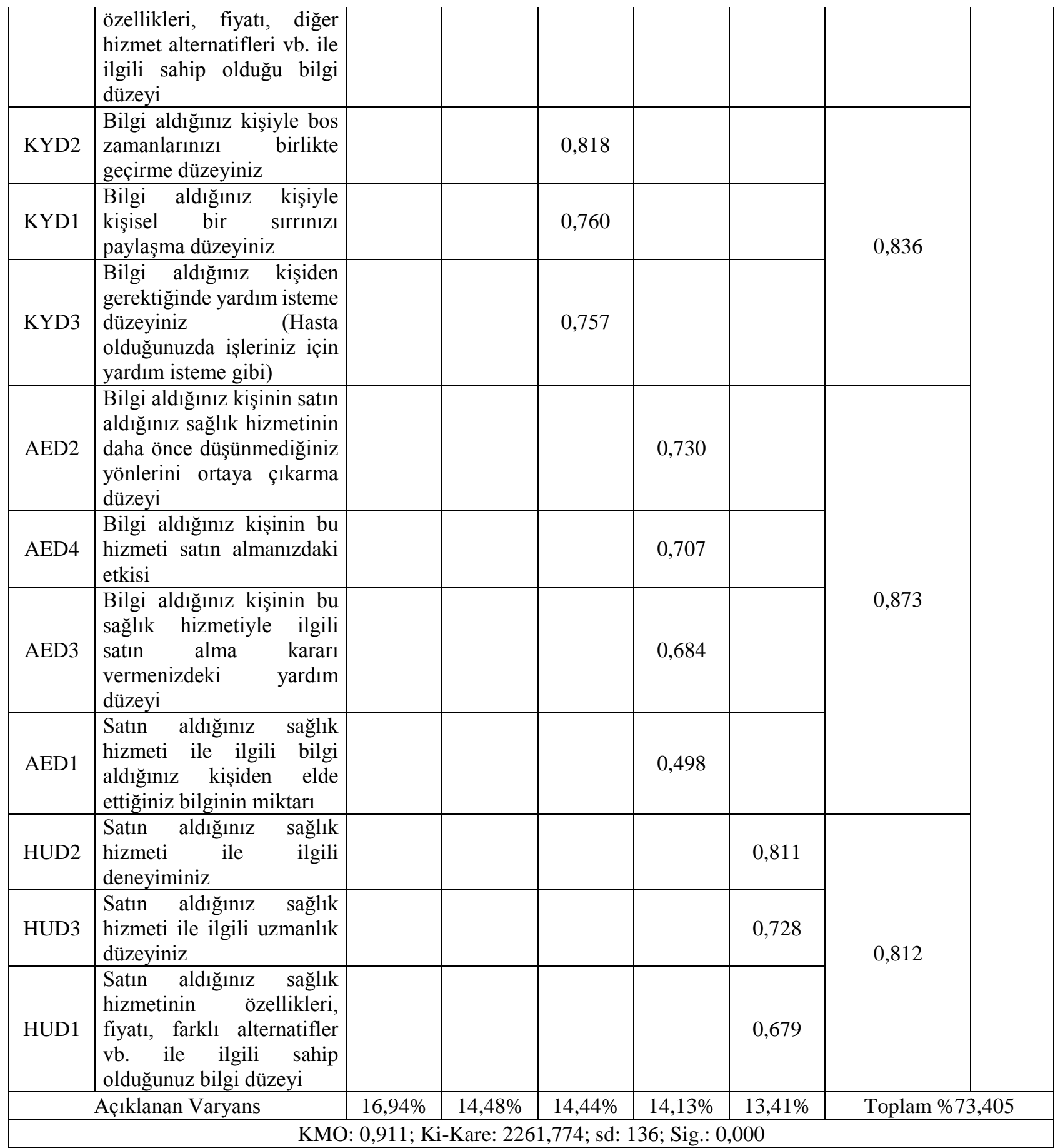

Tablo 2'de faktör ve güvenilirlik analizleri sonucunda elde edilmiş olan faktörlere ilişkin tanımlayıcı bulgular görülmektedir. Tabloda görüldüğü üzere; KYD faktörünün ortalaması $\bar{x}=3,6043$; KUD faktörünün ortalaması $\bar{x}=3,8766$; HUD faktörünün ortalaması $\bar{x}=3,7348$; ARD faktörünün ortalamas1 $\overline{\mathrm{x}}=3,8362$; AED faktörünün ortalaması $\overline{\mathrm{x}}=3,8755$ olarak saptanmıştır. Faktörlerin basıklık ve çarpıklık değerleri incelendiğinde, basıklık ve çarpıklık değerlerinin (-1) ile $(+1)$ arasında olmasından ötürü, verilerin normal (homojen) dağıldığı varsayımı kabul edilmiştir.

Tablo 2. Eıde Edilen Faktörlere İlişkin Tanımlayıcı Bulgular

\begin{tabular}{|c|c|c|c|c|c|c|c|}
\hline Faktör & Sayı & Min. & Maks. & Ort. & SS & Çarpıklık & Basıklık \\
\hline KYD & 235 & 1,00 & 5,00 & 3,6043 & 1,02573 & $-0,340$ & $-0,789$ \\
\hline KUD & 235 & 1,33 & 5,00 & 3,8766 & 0,76634 & $-0,582$ & 0,080 \\
\hline
\end{tabular}


Al-Farabi International Journal on Social Sciences

\begin{tabular}{|l|l|l|l|l|l|l|l|} 
HUD & 235 & 1,67 & 5,00 & 3,7348 & 0,87114 & $-0,441$ & $-0,521$ \\
\hline ARD & 235 & 1,00 & 5,00 & 3,8362 & 0,85533 & $-0,526$ & $-0,345$ \\
\hline AED & 235 & 2,00 & 5,00 & 3,8755 & 0,80741 & $-0,316$ & $-0,946$ \\
\hline
\end{tabular}

Tablo 3'te, katılımcıların A ğızdan Ağıza İletişim faktörlerine verdikleri yanıtların cinsiyete göre farklılaşıp farklılaşmadığını test etmek üzere yapılmış olan Bağımsız Örneklem T Testi bulguları görülmektedir. Tabloda yer alan sigma değerlerine göre, tüm faktörlerde $p>0,05$ olduğundan, hiçbir faktörde cinsiyete göre anlamlı farklılığa rastlanmamıştır. Buna göre, katılımcıların kadın veya erkek olmalarına göre, Ağızdan A ğıza iletişimle ilgili faktörlere verdikleri yanıtlar anlamlı bir farklılık göstermemektedir. Elde edilen bu bulgulara göre, "Hla = Bilgi alınan kişinin uzmanlık düzeyine verilen yanıtlar, cinsiyete göre farklılaşmaktadır.", "H2a = Bilgi alınan kişi ile yakınlık derecesine verilen yanitlar, cinsiyete göre farklılaşmaktadır.", "H3a = Hizmetle ilgili uzmanlık düzeyine verilen yanıtlar, cinsiyete göre farklılaşmaktadır.", " $\mathrm{H} 4 \mathrm{a}=$ Algılanan risk düzeyine verilen yanitlar, cinsiyete göre farklılaşmaktadır." ve "H5a = Ă̆ızdan ă̆lza iletişimin etki düzeyine verilen yanıtlar, cinsiyete göre farklılaşmaktadır." hipotezleri reddedilmiştir.

Tablo 3. Cinsiyete Göre Gerçekleştirilen Bağımsız Örneklem T Testi Bulguları

\begin{tabular}{|c|c|c|c|c|c|c|c|}
\hline Değişken & Cinsiyet & Sayı & Ort. & SS & t-değeri & sd & Sig. \\
\hline \multirow{2}{*}{ KYD } & Kadın & 115 & 3,5275 & 1,13080 & \multirow{2}{*}{$-1,123$} & \multirow{2}{*}{233} & \multirow{2}{*}{0,265} \\
\hline & Erkek & 120 & 3,6778 & 0,91255 & & & \\
\hline \multirow{2}{*}{ KUD } & Kadın & 115 & 3,9449 & 0,75436 & \multirow{2}{*}{1,340} & \multirow{2}{*}{233} & \multirow{2}{*}{0,181} \\
\hline & Erkek & 120 & 3,8111 & 0,77512 & & & \\
\hline \multirow{2}{*}{ HUD } & Kadın & 115 & 3,7391 & 0,80178 & \multirow{2}{*}{0,075} & \multirow{2}{*}{233} & \multirow{2}{*}{0,940} \\
\hline & Erkek & 120 & 3,7306 & 0,93615 & & & \\
\hline \multirow{2}{*}{ ARD } & Kadın & 115 & 3,7761 & 0,91549 & \multirow{2}{*}{$-1,054$} & \multirow{2}{*}{233} & \multirow{2}{*}{0,293} \\
\hline & Erkek & 120 & 3,8938 & 0,79300 & & & \\
\hline \multirow{2}{*}{ AED } & Kadın & 115 & 3,9000 & 0,78346 & \multirow{2}{*}{0,454} & \multirow{2}{*}{233} & \multirow{2}{*}{0,650} \\
\hline & Erkek & 120 & 3,8521 & 0,83231 & & & \\
\hline
\end{tabular}

Tablo 4'te, katılımcıların Ağızdan Ağıza İletişim faktörlerine verdikleri yanıtların yaş grubuna göre farklılaşıp farklılaşmadığını test etmek üzere yapılmış olan ANOVA Testi bulguları görülmektedir. Tabloda yer alan sigma değerlerine göre, tüm faktörlerde $p>0,05$ olduğundan, hiçbir faktörde yaş grubuna göre anlamlı farklılığa rastlanmamıştır. Buna göre, katılımcıların yaş gruplarına göre, Ağızdan Ağıza iletişimle ilgili faktörlere verdikleri yanıtlar anlamlı bir farklılık göstermemektedir. Elde edilen bu bulgulara göre, "H1b = Bilgi alınan kişinin uzmanlık düzeyine verilen yanıtlar, yaş grubuna göre farklılaşmaktadır.", "H2b = Bilgi alınan kişi ile yakınlık derecesine verilen yanıtlar, yaş grubuna göre farklılaşmaktadır.", "H3b = Hizmetle ilgili uzmanlık düzeyine verilen yanıtlar, yaş grubuna göre farklılaşmaktadır.", "H4b = Algllanan risk düzeyine verilen yanitlar, yaş grubuna göre farklılaşmaktadır." ve "H5b = Ă̆gzdan ăgıza iletişimin etki düzeyine verilen yanitlar, yaş grubuna göre farklılaşmaktadır." hipotezleri reddedilmiştir. 
Al-Farabi International Journal on Social Sciences

Tablo 4. Yaş Grubuna Göre Gerçekleştirilen ANOVA Testi Bulguları

\begin{tabular}{|c|c|c|c|c|c|c|}
\hline \multicolumn{2}{|c|}{ Değişken } & $\begin{array}{l}\text { Kareler } \\
\text { Toplam }\end{array}$ & sd & Ort. Karesi & F-değeri & Sig. \\
\hline \multirow{3}{*}{ KYD } & Gruplar aras1 & 0,350 & 3 & 0,117 & \multirow{3}{*}{0,110} & \multirow{3}{*}{0,954} \\
\hline & Gruplar içi & 245,846 & 231 & 1,064 & & \\
\hline & Toplam & 246,196 & 234 & & & \\
\hline \multirow{3}{*}{ KUD } & Gruplar aras1 & 0,415 & 3 & 0,138 & \multirow{3}{*}{0,233} & \multirow{3}{*}{0,873} \\
\hline & Gruplar içi & 137,007 & 231 & 0,593 & & \\
\hline & Toplam & 137,421 & 234 & & & \\
\hline \multirow{3}{*}{ HUD } & Gruplar aras1 & 1,930 & 3 & 0,643 & \multirow{3}{*}{0,846} & \multirow{3}{*}{0,470} \\
\hline & Gruplar içi & 175,647 & 231 & 0,760 & & \\
\hline & Toplam & 177,577 & 234 & & & \\
\hline \multirow{3}{*}{ ARD } & Gruplar aras1 & 2,923 & 3 & 0,974 & \multirow{3}{*}{1,338} & \multirow{3}{*}{0,263} \\
\hline & Gruplar içi & 168,269 & 231 & 0,728 & & \\
\hline & Toplam & 171,193 & 234 & & & \\
\hline \multirow{3}{*}{ AED } & Gruplar arası & 0,463 & 3 & 0,154 & \multirow{3}{*}{0,235} & \multirow{3}{*}{0,872} \\
\hline & Gruplar içi & 152,084 & 231 & 0,658 & & \\
\hline & Toplam & 152,547 & 234 & & & \\
\hline
\end{tabular}

Tablo 5'te, katılımcıların Ağızdan Ağıza İletişim faktörlerine verdikleri yanıtların eğitim durumuna göre farklılaşıp farklılaşmadığını test etmek üzere yapılmış olan ANOVA Testi bulguları görülmektedir. Tabloda yer alan sigma değerlerine göre, $\operatorname{HUD}(F=3,863 ; p=0,010)$ için $p<0,05$ olarak saptandığından, HUD faktörüne verilen yanıtlarda eğitim durumuna göre anlamlı farklılık bulunduğu tespit edilmiştir. Farklılığın nereden kaynaklandığını bulmak üzere gerçekleştirilen Tukey post hoc testi neticesinde; lisans mezunlarının ( $\overline{\mathrm{x}}=3,5044)$, lise mezunları $(\overline{\mathrm{x}}=3,8874)$ ve önlisans mezunlarına $(\bar{x}=3,9514)$ kıyasla daha düşük yanıtlar verdikleri bulgusu elde edilmiştir. Buna göre, eğitim düzeyi daha düşük olanların hizmetle ilgili bilgi düzeyleri daha yüksektir. Elde edilen bu bulgulara göre, "H3c = Hizmetle ilgili uzmanlık düzeyine verilen yanıtlar, ĕgitim düzeyine göre farklılaşmaktadır." hipotezi kabul edilmiş; "Hlc = Bilgi alınan kişinin uzmanlık düzeyine verilen yanttlar, eğitim düzeyine göre farklılaşmaktadır.", " $\mathrm{H} 2 c=$ Bilgi alınan kişi ile yakınlık derecesine verilen yanıtlar, eğitim düzeyine göre farklılaşmaktadır.", "H4c = Algllanan risk düzeyine verilen yanitlar, eğitim

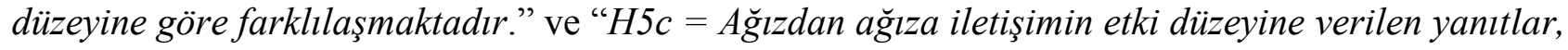
eğitim düzeyine göre farklılaşmaktadır." hipotezleri reddedilmiştir.

Tablo 5. Eğitim Durumuna Göre Gerçekleștirilen ANOVA Testi Bulguları

\begin{tabular}{|c|c|c|c|c|c|c|c|}
\hline \multicolumn{2}{|c|}{ Değişken } & $\begin{array}{l}\text { Kareler } \\
\text { Toplamı }\end{array}$ & sd & Ort. Karesi & F-değeri & Sig. & $\begin{array}{c}\text { Anlamlı } \\
\text { Fark }\end{array}$ \\
\hline \multirow{3}{*}{ KYD } & Gruplar aras1 & 3,714 & 3 & 1,238 & \multirow{3}{*}{1,180} & \multirow{3}{*}{0,318} & \\
\hline & Gruplar içi & 242,481 & 231 & 1,050 & & & \\
\hline & Toplam & 246,196 & 234 & & & & \\
\hline \multirow{3}{*}{ KUD } & Gruplar aras1 & 2,025 & 3 & 0,675 & \multirow{3}{*}{1,152} & \multirow{3}{*}{0,329} & \\
\hline & Gruplar içi & 135,396 & 231 & 0,586 & & & \\
\hline & Toplam & 137,421 & 234 & & & & \\
\hline \multirow{3}{*}{ HUD } & Gruplar aras1 & 8,483 & 3 & 2,828 & \multirow{3}{*}{3,863} & \multirow{3}{*}{0,010} & \multirow{3}{*}{$1-3,2-3$} \\
\hline & Gruplar içi & 169,094 & 231 & 0,732 & & & \\
\hline & Toplam & 177,577 & 234 & & & & \\
\hline \multirow{3}{*}{ ARD } & Gruplar aras1 & 3,661 & 3 & 1,220 & \multirow{3}{*}{1,682} & \multirow{3}{*}{0,172} & \\
\hline & Gruplar içi & 167,532 & 231 & 0,725 & & & \\
\hline & Toplam & 171,193 & 234 & & & & \\
\hline \multirow{3}{*}{ AED } & Gruplar arası & 2,513 & 3 & 0,838 & \multirow{3}{*}{1,290} & \multirow{3}{*}{0,279} & \\
\hline & Gruplar içi & 150,034 & 231 & 0,649 & & & \\
\hline & Toplam & 152,547 & 234 & & & & \\
\hline
\end{tabular}


Tablo 6'da katılımcıların A ğızdan Ağıza İletişim faktörlerine verdikleri yanıtların medeni durumuna göre farklılaşıp farklılaşmadığını test etmek üzere yapılmış olan ANOVA Testi bulguları görülmektedir. Tabloda yer alan sigma değerlerine göre, KYD ( $F=4,439 ; p=0,013)$; HUD ( $F=5,891$; $\mathrm{p}=0,003)$; $\operatorname{ARD}(\mathrm{F}=3,554 ; \mathrm{p}=0,030)$ ve $\operatorname{AED}(\mathrm{F}=4,734 ; \mathrm{p}=0,010)$ için $\mathrm{p}<0,05$ olarak saptandığından, bu faktörlere verilen yanıtlarda medeni duruma göre anlamlı farklılıklar bulunduğu tespit edilmiştir. Farklılığın nereden kaynaklandığını bulmak üzere gerçekleştirilen Tukey post hoc testi neticesinde:

i. KYD faktöründe bekar katılımcılar $(\overline{\mathrm{x}}=3,5632)$ ile evli katılımcıların $(\overline{\mathrm{x}}=3,5000)$, diğer seçeneğini işaretleyen katılımcılara $(\overline{\mathrm{x}}=4,0938)$ göre daha düşük yanıtlar verdikleri belirlenmiştir.

ii. HUD faktöründe bekar katılımcılar $(\overline{\mathrm{x}}=3,7586)$ ile evli katılımcıların $(\overline{\mathrm{x}}=3,5948)$, diğer seçeneğini işaretleyen katılımcılara $(\overline{\mathrm{x}}=4,1771)$ göre daha düşük yanıtlar verdikleri belirlenmiştir.

iii. ARD faktöründe evli katılımcıların $(\overline{\mathrm{x}}=3,7457)$, diğer seçeneğini işaretleyen katılımcılara $(\overline{\mathrm{x}}=4,1953)$ göre daha düşük yanıtlar verdikleri belirlenmiştir.

iv. AED faktöründe evli katılımcıların $(\overline{\mathrm{x}}=3,7478)$, diğer seçeneğini işaretleyen katılımcılara $(\overline{\mathrm{x}}=4,2266)$ göre daha düşük yanıtlar verdikleri belirlenmiştir.

Elde edilen bu bulgulara göre, "H1d = Bilgi alınan kişinin uzmanlık düzeyine verilen yanıtlar, medeni duruma göre farklılaşmaktadır.", "H3d = Hizmetle ilgili uzmanlık düzeyine verilen yanitlar, medeni duruma göre farklılaşmaktadır.", "H4d = Algllanan risk düzeyine verilen yanıtlar, medeni duruma göre farklılaşmaktadır." ve "H5d = Ă̆gzdan ă̆ıza iletişimin etki düzeyine verilen yanıtlar, medeni duruma göre farklılaşmaktadır." hipotezleri kabul edilmiş; "H2d = Bilgi alınan kişi ile yakınlık derecesine verilen yanıtlar, medeni duruma göre farklılaşmaktadır." hipotezi reddedilmiştir.

Tablo 6. Medeni Duruma Göre Gerçekleştirilen ANOVA Testi Bulguları

\begin{tabular}{|c|c|c|c|c|c|c|c|}
\hline \multicolumn{2}{|c|}{ Değişken } & $\begin{array}{l}\text { Kareler } \\
\text { Toplam }\end{array}$ & sd & $\begin{array}{c}\text { Ort. } \\
\text { Karesi }\end{array}$ & F-değeri & Sig. & $\begin{array}{c}\text { Anlamlı } \\
\text { Fark }\end{array}$ \\
\hline \multirow{3}{*}{ KYD } & Gruplar aras1 & 9,075 & 2 & 4,537 & \multirow{3}{*}{4,439} & \multirow{3}{*}{0,013} & \multirow{3}{*}{$3-1,3-2$} \\
\hline & Gruplar içi & 237,121 & 232 & 1,022 & & & \\
\hline & Toplam & 246,196 & 234 & & & & \\
\hline \multirow{3}{*}{ KUD } & Gruplar aras1 & 3,304 & 2 & 1,652 & \multirow{3}{*}{2,857} & \multirow{3}{*}{0,059} & \\
\hline & Gruplar içi & 134,117 & 232 & 0,578 & & & \\
\hline & Toplam & 137,421 & 234 & & & & \\
\hline \multirow{3}{*}{ HUD } & Gruplar aras1 & 8,582 & 2 & 4,291 & \multirow{3}{*}{5,891} & \multirow{3}{*}{0,003} & \multirow{3}{*}{$3-1,3-2$} \\
\hline & Gruplar içi & 168,996 & 232 & 0,728 & & & \\
\hline & Toplam & 177,577 & 234 & & & & \\
\hline \multirow{3}{*}{ ARD } & Gruplar aras1 & 5,089 & 2 & 2,544 & \multirow{3}{*}{3,554} & \multirow{3}{*}{0,030} & \multirow{3}{*}{$3-2$} \\
\hline & Gruplar içi & 166,104 & 232 & 0,716 & & & \\
\hline & Toplam & 171,193 & 234 & & & & \\
\hline \multirow{3}{*}{ AED } & Gruplar aras1 & 5,982 & 2 & 2,991 & \multirow{3}{*}{4,734} & \multirow{3}{*}{0,010} & \multirow{3}{*}{$3-2$} \\
\hline & Gruplar içi & 146,565 & 232 & 0,632 & & & \\
\hline & Toplam & 152,547 & 234 & & & & \\
\hline
\end{tabular}

Tablo 7'de katılımcıların Ağızdan Ağıza İletişim faktörlerine verdikleri yanıtların aylık hanehalkı gelir durumuna göre farklılaşıp farklılaşmadığını test etmek üzere yapılmış olan ANOVA Testi bulguları görülmektedir. Tabloda yer alan sigma değerlerine göre, HUD ( $F=3,902 ; p=0,010)$; ARD $(\mathrm{F}=4,477 ; \mathrm{p}=0,004)$ ve AED $(\mathrm{F}=2,745 ; \mathrm{p}=0,044)$ için $\mathrm{p}<0,05$ olarak saptandığından, bu faktörlere verilen yanıtlarda aylık hanehalkı gelir durumuna göre anlamlı farklılıklar bulunduğu tespit edilmiştir. Farklılığın nereden kaynaklandığını bulmak üzere gerçekleştirilen Tukey post hoc testi neticesinde: 
i. HUD faktöründe aylık hanehalkı geliri 2.500 TL'den az olan katılımcılar ( $\overline{\mathrm{x}}=3,9303)$ ile 2.500 TL -5.000 TL arasinda olan katılımciların $(\overline{\mathrm{x}}=3,8817), 7.500$ TL'den fazla olan katılımcilara $(\bar{x}=3,5179)$ göre daha yüksek yanıtlar verdikleri belirlenmiştir.

ii. ARD faktöründe aylık hanehalkı geliri 2.500 TL'den az olan katılımcıların ( $\bar{x}=4,1269), 2.500$ $\mathrm{TL}-5.000 \mathrm{TL}$ arasında olan katılımcılara $(\overline{\mathrm{x}}=3,7016)$ ve $7.500 \mathrm{TL}$ 'den fazla olan katılımcilara göre daha yüksek yanıtlar verdikleri belirlenmiştir.

iii. AED faktöründe aylık hanehalk1 geliri 2.500 TL'den az olan katılımcıların $(\overline{\mathrm{x}}=4,0746), 7.500$ TL'den fazla olan katılımcılara $(\overline{\mathrm{x}}=3,6920)$ göre daha yüksek yanıtlar verdikleri belirlenmiştir.

Elde edilen bu bulgulara göre, "H3e = Hizmetle ilgili uzmanlık düzeyine verilen yanitlar, aylık hanehalkı gelir durumuna göre farklılaşmaktadır." "H4e = Algllanan risk düzeyine verilen yanıtlar, aylık hanehalkı gelir durumuna göre farklılaşmaktadır." ve "H5e = Ăgızdan ăgıza iletişimin etki düzeyine verilen yanıtlar, aylık hanehalkı gelir durumuna göre farklılaşmaktadır." hipotezleri kabul edilmiş; "Hle = Bilgi alınan kişinin uzmanlık düzeyine verilen yanttlar, aylık hanehalkı gelir durumuna göre farklılaşmaktadır." ve "H2e = Bilgi alınan kişi ile yakılılk derecesine verilen yanıtlar, aylık hanehalkı gelir durumuna göre farklılaşmaktadır." hipotezleri reddedilmiştir.

Tablo 7. Aylık Hanehalkı Gelir Durumuna Göre Gerçekleştirilen ANOVA Testi Bulguları

\begin{tabular}{|c|c|c|c|c|c|c|c|}
\hline & & $\begin{array}{l}\text { Kareler } \\
\text { Toplamı }\end{array}$ & sd & $\begin{array}{c}\text { Ort. } \\
\text { Karesi }\end{array}$ & F-değeri & Sig. & $\begin{array}{c}\text { Anlamlı } \\
\text { Fark }\end{array}$ \\
\hline \multirow{3}{*}{ KYD } & Gruplar arası & 4,382 & 3 & 1,461 & \multirow{3}{*}{1,395} & \multirow{3}{*}{0,245} & \\
\hline & Gruplar içi & 241,814 & 231 & 1,047 & & & \\
\hline & Toplam & 246,196 & 234 & & & & \\
\hline \multirow{3}{*}{ KUD } & Gruplar aras1 & 3,353 & 3 & 1,118 & \multirow{3}{*}{1,926} & \multirow{3}{*}{0,126} & \\
\hline & Gruplar içi & 134,068 & 231 & 0,580 & & & \\
\hline & Toplam & 137,421 & 234 & & & & \\
\hline \multirow{3}{*}{ HUD } & Gruplar aras1 & 8,565 & 3 & 2,855 & \multirow{3}{*}{3,902} & \multirow{3}{*}{0,010} & \multirow{3}{*}{$1-4,2-4$} \\
\hline & Gruplar içi & 169,012 & 231 & 0,732 & & & \\
\hline & Toplam & 177,577 & 234 & & & & \\
\hline \multirow{3}{*}{ ARD } & Gruplar aras1 & 9,406 & 3 & 3,135 & \multirow{3}{*}{4,477} & \multirow{3}{*}{0,004} & \multirow{3}{*}{$1-2,1-4$} \\
\hline & Gruplar içi & 161,787 & 231 & 0,700 & & & \\
\hline & Toplam & 171,193 & 234 & & & & \\
\hline \multirow{3}{*}{ AED } & Gruplar arası & 5,252 & 3 & 1,751 & \multirow{3}{*}{2,745} & \multirow{3}{*}{0,044} & \multirow{3}{*}{$1-4$} \\
\hline & Gruplar içi & 147,295 & 231 & 0,638 & & & \\
\hline & Toplam & 152,547 & 234 & & & & \\
\hline
\end{tabular}

Tablo 8'de katılımcıların Ağızdan Ağıza İletişim faktörlerine verdikleri yanıtların çalışma durumuna göre farklılaşıp farklılaşmadığını test etmek üzere yapılmış olan Bağımsız Örneklem T Testi bulguları görülmektedir. Tabloda yer alan sigma değerlerine göre, HUD $(\mathrm{t}=-2,479 ; \mathrm{p}=0,014)$ ve ARD ( $\mathrm{t}=-$ 2,303; $p=0,022)$ için $p<0,05$ şeklinde saptandığından, bu faktörlere verilen yanıtlarda çalışma durumuna göre anlamlı farklılıklar bulunduğu tespit edilmiştir. Tabloda görüldüğü üzere, her iki faktör için de çalışmayanlar çalışanlara kıyasla daha yüksek yanıtlar vermişlerdir. Buna göre, çalışmayan katılımcıların hizmetle ilgili bilgi düzeyleri ve algıladıkları risk düzeyleri, çalışanlara nazaran daha yüksektir. Elde edilen bu bulgulara göre, "H3f = Hizmetle ilgili uzmanlık düzeyine verilen yanıtlar, çalışma durumuna göre farklılaşmaktadır." ve " $H 4 f=$ Algılanan risk düzeyine verilen yanıtlar, çalışma durumuna göre farklılaşmaktadır." hipotezleri kabul edilmiş; "Hlf = Bilgi alınan kişinin uzmanlık düzeyine verilen yanıtlar, çalışma durumuna göre farklılaşmaktadır.", "H2f = Bilgi alınan kişi ile yakınlık derecesine verilen yanıtlar, çalışma durumuna göre farklılaşmaktadır." 


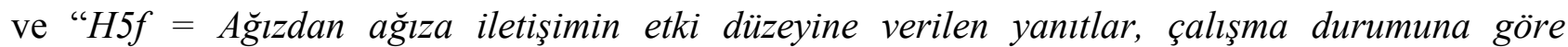
farklılaşmaktadır." hipotezleri reddedilmiştir.

Tablo 8. Çalışma Durumuna Göre Gerçekleştirilen Bağımsız Örneklem T Testi Bulguları

\begin{tabular}{|c|c|c|c|c|c|c|c|}
\hline Değişken & Çalışma Durumu & Sayı & Ort. & SS & t-değeri & sd & Sig. \\
\hline \multirow{2}{*}{ KYD } & Evet & 163 & 3,5951 & 0,99708 & \multirow{2}{*}{$-0,206$} & \multirow{2}{*}{233} & \multirow{2}{*}{0,837} \\
\hline & Hayır & 72 & 3,6250 & 1,09478 & & & \\
\hline \multirow{2}{*}{ KUD } & Evet & 163 & 3,8405 & 0,74198 & \multirow{2}{*}{$-1,087$} & \multirow{2}{*}{233} & \multirow{2}{*}{0,278} \\
\hline & Hayır & 72 & 3,9583 & 0,81829 & & & \\
\hline \multirow{2}{*}{ HUD } & Evet & 163 & 3,6421 & 0,86508 & \multirow{2}{*}{$-2,479$} & \multirow{2}{*}{233} & \multirow{2}{*}{0,014} \\
\hline & Hayır & 72 & 3,9444 & 0,85397 & & & \\
\hline \multirow{2}{*}{ ARD } & Evet & 163 & 3,7515 & 0,83449 & \multirow{2}{*}{$-2,303$} & \multirow{2}{*}{233} & \multirow{2}{*}{$\mathbf{0 , 0 2 2}$} \\
\hline & Hayır & 72 & 4,0278 & 0,87669 & & & \\
\hline \multirow{2}{*}{ AED } & Evet & 163 & 3,8267 & 0,78878 & \multirow{2}{*}{$-1,398$} & \multirow{2}{*}{233} & \multirow{2}{*}{0,163} \\
\hline & Hayır & 72 & 3,9861 & 0,84325 & & & \\
\hline
\end{tabular}

Gerçekleştirilen hipotez testleri neticesinde, araştırmanın ana hipotezleri ile ilintili olarak şu bulgulara erişilmiştir:

i. $\quad$ "H1 = Bilgi alınan kişinin uzmanlık düzeyine verilen yanıtlar, demografik özelliklere göre farklılaşmaktadır." ana hipotezi; H1a, H1b, H1c, H1e ve H1f hipotezlerinin reddedilmesi ve H1d hipotezinin kabul edilmesinden ötürü, kısmen kabul edilmiştir.

ii. " $H 2$ = Bilgi alınan kişi ile yakınlık derecesine verilen yanıtlar, demografik özelliklere göre farklılaşmaktadır." ana hipotezi; H2a, H2b, H2c, H2d, H2e ve H2f hipotezlerinin reddedilmesinden ötürü, reddedilmiştir.

iii. "H3 = Hizmetle ilgili uzmanlık düzeyine verilen yanitlar, demografik özelliklere göre farklılaşmaktadır." ana hipotezi; H3a ve H3b hipotezlerinin reddedilmesi ve H3c, H3d, H3e ve H3f hipotezlerinin kabul edilmesinden ötürü, kısmen kabul edilmiştir.

iv. "H4 = Algllanan risk düzeyine verilen yanıtlar, demografik özelliklere göre farklılaşmaktadır." ana hipotezi; $\mathrm{H} 4 \mathrm{a}, \mathrm{H} 4 \mathrm{~b}$ ve $\mathrm{H} 4 \mathrm{c}$ hipotezlerinin reddedilmesi ve $\mathrm{H} 4 \mathrm{~d}$, H4e ve H4f hipotezlerinin kabul edilmesinden ötürü, kısmen kabul edilmiştir.

v. "H5 = Ă̆gzdan ăgıza iletişimin etki düzeyine verilen yanıtlar, demografik özelliklere göre farklılaşmaktadır." ana hipotezi; H5a, H5b, H5c ve H5f hipotezlerinin reddedilmesi ve H5d ve H5e hipotezlerinin kabul edilmesinden ötürü, kısmen kabul edilmiştir.

\section{SONUÇ VE TARTIŞMA}

$\mathrm{Bu}$ çalışma çerçevesinde, sağlık sektöründe sağlık tüketicileri tarafından gerçekleştirilen ağızdan ağıza iletişim faaliyetlerinin tüketicilerin demografik özelliklerine göre farklılaşma durumunun incelenmesi amaçlanmıştır. Bu doğrultuda Mardin ilinde yaşayan sağlık tüketicileri ile bir anket uygulaması gerçekleştirilmiştir. Verilerin toplanması sonrasında yapılan faktör ve güvenilirlik analizlerinde, orijinal ölçeklerle uyumlu bulgular elde edilmiştir.

Çalışma kapsamında cinsiyete göre yapılan farklılık analizleri neticesinde, herhangi bir faktörde anlamlı farklılığa rastlanmamıştır. Bu doğrultuda, katılımcıların kadın veya erkek olmalarına göre, Ağızdan Ağıza iletişimle ilgili faktörlere verdikleri yanıtların anlamlı bir farklılık göstermediği söylenebilir. Orak (2018) tarafından yapılan çalışmada, cinsiyete göre AED-KUD ve KYD faktörlerinde anlamlı farklılık saptanırken; HUD ve ARD faktörlerinde anlamlı farklılığa rastlanmamıştır. Ayaydın (2019) tarafından yapılan araştırmada, cinsiyete göre ARD faktöründe anlamlı farklılığa rastlanırken; KUD, HUD ve AED faktörlerinde anlamlı farklılığa rastlanmamıştır. 
Gürcü (2018) tarafından yapılan çalışmada, cinsiyete göre ARD faktöründe anlamlı farklılığa rastlanırken; KUD, HUD ve AED faktörlerinde anlamlı farklılığa rastlanmamıştır. Ayrıca Kılıçer (2006) tarafından yapılan çalışmada da yalnızca ARD faktörüne ilişkin analiz gerçekleştirilmiş ve anlamlı bir farklılığa rastlanmamıştır. Bu bağlamda, cinsiyete ilişkin olarak çalışmada elde edilen bulguların literatür bulguları ile farklılığa sahip olduğu yorumu yapılabilir. Bu farklılıkların nedeni, çalışmalarda üzerinde çalışılmış olan örneklem gruplarının yapısal farklılıkları olabilir.

Yaş grubuna göre yapılan farklılık analizleri neticesinde, herhangi bir faktörde anlamlı farklılığa rastlanmamıştır. Bu doğrultuda, katılımcıların yaşlarına göre, Ağızdan Ağıza iletişimle ilgili faktörlere verdikleri yanıtların anlamlı bir farklılık göstermediği söylenebilir. Orak (2018) tarafından yapılan çalışmada da yaş grubuna göre hiçbir faktörde anlamlı farklılığa rastlanmamıştır. Ayaydın (2019) tarafından yapılan araştırmada da yaş grubuna göre hiçbir faktörde anlamlı farklılığa rastlanmamıştır. Gürcü (2018) tarafından yapılan çalışmada, yaş grubuna göre, tüm faktörlerde anlamlı farklılıklar tespit edilmiştir. Ayrıca Kılıçer (2006) tarafından yapılan çalışmada da yalnızca ARD faktörüne ilişkin analiz gerçekleştirilmiş ve anlamlı bir farklılığa rastlanmamıştır. Bu bağlamda, yaş grubuna ilişkin olarak çalışmada elde edilen bulgularla literatürdeki önceki çalışmaların bulguların paralel olduğu yorumu yapılabilir.

Eğitim durumuna göre yapılan farklılık analizleri neticesinde, sadece HUD faktöründe anlamlı farklılığa rastlanmış olup, lise ve önlisans mezunlarının lisans mezunlarına nazaran sağlık hizmetiyle ilgili kendi bilgi düzeylerinin daha yüksek olduğu tespit edilmiştir. Bu farklılığın nedeni, eğitim düzeyi yükseldikçe bilimsel bilgi ihtiyacının artış göstermesi, bu doğrultuda lisans mezunlarının bilimsel bilgilere itibarının yakın çevreden aldıkları bilgiye kıyasla daha fazla olması olabilir. Orak (2018) tarafından yapılan çalışmada ise eğitim durumuna göre AED-KUD, KYD ve ARD faktörlerinde anlamlı farklılık saptanırken; HUD faktöründe anlamlı farklılığa rastlanmamıştır. Ayaydın (2019) tarafından yapılan araştırmada eğitim durumuna göre, ARD faktöründe anlamlı farklılığa rastlanırken; diğer faktörlerde anlamlı farklılığa rastlanmamıştır. Gürcü (2018) tarafından yapılan çalışmada, eğitim durumuna göre, herhangi bir faktörde anlamlı farklılık tespit edilmemiştir. $\mathrm{Bu}$ bağlamda, eğitim durumuna ilişkin olarak, çalışmaların bulguları arasında farklılık olduğu yorumu yapılabilir. Bu farklılığın nedeni, çalışmalarda üzerinde çalışılmış olan örneklem gruplarının yapısal farklılıkları olabilir.

Medeni duruma göre yapılan farklılık analizleri neticesinde, KYD, HUD, ARD ve AED faktörlerinde anlamlı farklılıklara rastlanmıştır. KYD faktörü için bekar katılımcılar ile evli katılımcıların, diğer seçeneğini işaretleyen katılımcılara nazaran sağlık hizmetiyle ilgili bilgi aldıkları kişi veya kişilerle olan yakınlık derecelerinin daha düşük olduğu tespit edilmiştir. HUD faktörü için bekar katılımcılar ile evli katılımcıların, diğer seçeneğini işaretleyen katılımcılara nazaran sağlık hizmetiyle ilgili kendi bilgi düzeylerinin daha düşük olduğu tespit edilmiştir. ARD faktörü için evli katılımcıların, diğer seçeneğini işaretleyen katılımcılara nazaran algıladıkları risk ve kaygı düzeyinin daha düşük olduğu tespit edilmiştir. AED faktörü için evli katılımcıların, diğer seçeneğini işaretleyen katılımcılara nazaran sağlık hizmetiyle ilgili ağızdan ağıza etkileşim düzeylerinin daha düşük olduğu tespit edilmiştir. Orak (2018) tarafından yapılan çalışmada ise medeni duruma göre hiçbir faktörde anlamlı farklılığa rastlanmamıştır. Ayaydın (2019) tarafından yapılan çalışmada ise medeni duruma göre hiçbir faktörde anlamlı farklılığa rastlanmamıştır. Gürcü (2018) tarafından yapılan çalışmada, medeni duruma göre, HUD ve ARD faktörlerinde anlamlı farklılıklara rastlanırken; KUD ve AED faktörlerinde anlamlı farklılığa rastlanmamıştır. Ayrıca Kılıçer (2006) tarafından yapılan çalışmada da yalnızca ARD faktörüne ilişkin analiz gerçekleştirilmiş ve anlamlı bir farklılığa rastlanmamıştır. Bu bağlamda, medeni duruma ilişkin olarak çalışmada elde edilen bulguların literatür bulguları ile farklılığa sahip olduğu yorumu yapılabilir. Bu farklılıkların nedeni, çalışmalarda üzerinde çalışılmış olan örneklem gruplarının yapısal farklılıkları olabilir.

Aylık hanehalkı gelir durumuna göre yapılan farklılık analizleri neticesinde, HUD, ARD ve AED faktörlerinde anlamlı farklılıklara rastlanmıştır. HUD faktörü için aylık hanehalkı geliri 2.500 TL'den az olan katılımcılarla 2.500 TL - 5.000 TL arasında olan katılımciların, 7.500 TL'den fazla olan katılımcılara nazaran sağlık hizmetiyle ilgili kendi bilgi düzeylerinin daha yüksek olduğu tespit 
edilmiştir. ARD faktörü için aylık hanehalkı geliri 2.500 TL'den az olan katılımcılarla 2.500 TL 5.000 TL arasında olan katılımcıların, 7.500 TL'den fazla olan katılımcılara nazaran sağlık hizmetiyle ilgili algıladıkları risk ve kaygı düzeyinin daha yüksek olduğu tespit edilmiştir. AED faktörü için aylık hanehalkı geliri 2.500 TL'den az olan katılımcıların, 7.500 TL'den fazla olan katılımcılara nazaran sağlık hizmetiyle ilgili ağızdan ağıza etkileşim düzeylerinin daha yüksek olduğu tespit edilmiştir. Ayaydın (2019) tarafından yapılan araştırmada ise gelir durumuna göre, KUD ve ARD faktörlerinde anlamlı farklılıklara rastlanırken; HUD ve AED faktörlerinde anlamlı farklılığa rastlanmamıştır. Gürcü (2018) tarafından yapılan çalışmada, aylık gelire göre, sadece HUD faktöründe anlamlı farklılığa rastlanmıştır. Bu bağlamda, aylık hanehalkı gelir durumuna ilişkin olarak çalışmada elde edilen bulguların literatür bulguları ile farklılığa sahip olduğu yorumu yapılabilir. Bu farklılıkların nedeni, çalışmalarda üzerinde çalışılmış olan örneklem gruplarının yapısal farklılıkları olabilir.

Son olarak, çalışma durumuna göre yapılan farklılık analizleri neticesinde, HUD ve ARD faktörlerinde çalışmayan katılımcılar lehine anlamlı farklılıklar tespit edilmiştir.

Sonuç olarak, sağlık sektöründe sağlık tüketicileri tarafından gerçekleştirilen ağızdan ağıza iletişim faaliyetlerinin tüketicilerin demografik özelliklerine göre farklllaşma durumunun incelendiği bu çalışmada, lietaratüre katkıda bulunacak önemli bulgulara rastlanmıştır. Bu doğrultuda, çalışmada elde edilen bulgulara göre, ağızdan ağıza iletişim faaliyetlerinin sağlık sektöründe bilgi alışverişi hususunda önemli bir rolünün bulunduğu ve çeşitli demografik özelliklere göre ağızdan ağıza iletişim faaliyetlerinin farklılaşma durumu gösterdiği söylenebilir. Bu bağlamda, sağlık kurumlarının yöneticilerinin de tüketicilere sunulmakta olan sağlık hizmetlerinde hizmet kalitesiyle güven faktörlerine odaklanarak çalışmaları gerektiği önerisinde bulunulabilir.

$\mathrm{Bu}$ çalışmanın çeşitli sınırlılıkları bulunmaktadır. Konu sınırlılı̆̆ı açısından araştırma, sağlık hizmetleri ve ağızdan ağıza iletişim konularıyla sınırlıdır. Bununla birlikte araştırma, anket formunda yer alan sorular ve ölçek maddeleriyle sınırlandırılmıştır. Örneklem bakımından araştırma, Mardin ilindeki sağlık hizmetleri tüketicileri ile sınırlı durumdadır. Araştırmada zaman sınırlılığı vardır. Zira çalışmaya ilişkin anket uygulaması 10 Mart 2020 ile 5 Nisan 2020 arasında gerçekleştirilmiştir.

Gelecekte yapılabilecek araştırmalar için, farklı örneklem gruplarının üzerinde, farklı illerle ilçelerde benzer çalışmalar gerçekleştirilmesi önerilebilir. Bunun yanı sıra, ağızdan ağıza ileitşim ve eletronik ağızdan ağıza iletişimin sağlık sektöründe tüketici davranışı ve tutumu üzerindeki etkisine ilişkin araştırmalar gerçekleştirilebilir.

\section{KAYNAKÇA}

Akdur, R. (2003). Să̆llk Sektör, Temel Kavramlar, Türkiye ve Avrupa Birliği’nde Durum ve Türkiye'nin Birliğe Uyumu. Ankara: Ankara Üniversitesi Basımevi.

Altay, A. (2007). Sağlık Hizmetlerinin Sunumunda Yeni Açılımlar ve Türkiye Açısından Değerlendirilmesi. Saylştay Dergisi, (64): 33-58.

Ateş, H. ve Kırılmaz, H. (2013). Bir Yönetişim Modeli Örneği: Kamu Hastane Birliği, A. H. Aydın, İ. E. Taş, M. Kılıç ve Z. Gül (Eds.), Küreselleşme Karşısında Kamu Yönetimi ve Hizmeti içinde, 229250. Kahramanmaraş: Kahramanmaraş Sütçü İmam Üniversitesi Yayınları.

Ayaydın, Z. (2019). Ağızdan Ağıza Pazarlama İletişiminin Sağlık Hizmetlerinden Yararlanan Tüketicilerin Satın Alma Kararına Etkisi: Şanlıurfa Örneği. Yayınlanmamış Yüksek Lisans Tezi. Hasan Kalyoncu Üniversitesi, Sosyal Bilimler Enstitüsü, Gaziantep.

Bodur, S. (1991). Aile Sağlı̆̆ı. Ankara: Başbakanlık Aile Araştırma Kurumu Başkanlığı Yayınları.

Çelikkan, A. C. (2009). Ağızdan Ağıza Pazarlama ile Satın Alma Esnasında Karşılaşılan Sürpriz Arasındaki İlişkinin Belirlenmesine Yönelik Bir Pilot Araştırma. Yayınlanmamış Yüksek Lisans Tezi. İstanbul Üniversitesi, Sosyal Bilimler Enstitüsü, İstanbul. 
Derbaix, C. and Vanhamme, J. (2003). Inducing Word-of-Mouth by Eliciting Surprise--A Pilot Investigation. Journal of Economic Psychology, 24 (1): 99-116.

Ersöz, F. (2008). Türkiye ile OECD Ülkelerinin Sağlık Düzeyleri ve Sağlık Harcamalarının Analizi. Istatistikçiler Dergisi, (2): 95-104.

Gremler, D. D., Gwinner, K. P. and Brown, S. W. (2001). Generating Positive Word-of-Mouth Communication Through Customer-Employee Relationships. International Journal of Service Industry Management, 12 (1): 44-59.

Gürcü, M. (2018). Ağızdan Ağıza İletişimin Sağlık Hizmetleri Pazarlamasındaki Önemi ve Tüketicilerin Sağlık Hizmeti Kullanım Tercihi Üzerindeki Etkisi. Yayınlanmamış Doktora Tezi. Gazi Üniversitesi, Sosyal Bilimler Enstitüsü, Ankara.

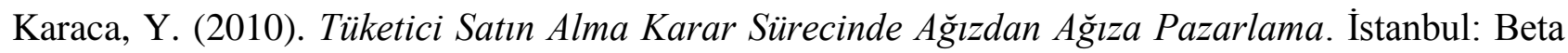
Yayınları.

Kavuncubaşı, Ş. ve Yıldırım, S. (2010). Hastane ve Sağllk Kurumları Yönetimi. Ankara: Siyasal Kitabevi.

Kılıç, M. ve Öztürk, H. (2006). Hastanelerde Mesai Saatleri Dışında Yürütülen Yönetim Hizmetleri: Ankara İli Eğitim Hastanelerinde Bir Alan Araştırması. Hacettepe Sağlık İdaresi Dergisi, 9 (1): $55-$ 79.

Kılıçer, T. (2006). Tüketicilerin Satın Alma Kararlarında Ağızdan Ağıza İletişimin Etkisi: Anadolu Üniversitesi Öğretim Elemanları Üzerinde Bir Araştırma. Yayınlanmamış Yüksek Lisans Tezi. Anadolu Üniversitesi, Sosyal Bilimler Enstitüsü, Eskişehir.

Kitapcı, O. (2008). Restoran Hizmetlerinde Müşteri Şikâyet Davranışları: Sivas İlinde Bir Uygulama. Erciyes Üniversitesi Íktisadi ve İdari Bilimler Fakültesi Dergisi, (31): 111-120.

Kozinets, R. B., De Valck, K., Wojnicki, A. C. and Wilner, S. J. S. (2010). Networked Narratives: Understanding Word-of-Mouth Marketing in Online Communities. Journal of Marketing, 74 (2): 7189.

Kurtulmuş, S. (1998). Să̆llk Ekonomisi ve Hastane Yönetimi. İstanbul: Değişim Dinamikleri Yayınevi.

Martin, S. (2016). Word-of-Mouth in the Health Care Sector: A Literature Analysis of the Current State of Research and Future Perspectives. International Review on Public and Nonprofit Marketing, 14 (1): 35-56.

Mutlu, A. ve Işık, K. (2012). Sağllk Ekonomisine Giriş. Bursa: Ekin Basım Yayın Dağıtım.

Orak, H. (2018). Sağlık Hizmetleri Pazarlamasında Tüketicilerin Demografik Verilerine Göre Ağızdan Ağıza İletişimin Etkililiği Üzerine Bir Araştırma. Yayınlanmamış Yüksek Lisans Tezi. İstanbul Aydın Üniversitesi, Sosyal Bilimler Enstitüsü, İstanbul.

Öz, İ. D. (2016). The Effects of Word-of-Mouth Communication on Purchasing Decision in Healthcare Marketing. Unpublished Master Thesis. Bahçeşehir University, Graduate School of Social Sciences, Istanbul.

Öz, M. ve Uyar, E. (2014). Sağlık Hizmetleri Pazarlamasında Algılanan Hizmet Kalitesi ve Müşteri Memnuniyeti Üzerinde Ağızdan Ağıza Pazarlamanın Etkisini Belirlemeye Yönelik Bir Araştırma. Karamanoğlu Mehmet Bey Üniversitesi Sosyal ve Ekonomik Araştırmalar Dergisi, 16 (26): 123-132.

Özuysal, H. (2011). Türkiye'de Sağlık Harcamaları: Ekonometrik Bir Uygulama. Yayınlanmamış Yüksek Lisans Tezi. Gazi Üniversitesi, Sosyal Bilimler Enstitüsü, Ankara.

Sarvan, F. (1995). Gelişmiş Ülkelerde ve Türkiye'de Sağlı Hizmetleri Yöneticiliği Meslek ve Eğitimi, H. Seçim (Eds.), Hastane Iş̧letmeciliği içinde, 1-28. Eskişehir: Anadolu Üniversitesi Yayınları. 


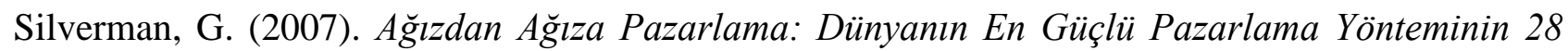
Sırrı, Çev. E. Orfanlı. İstanbul: Mediacat Yayınları.

Somunoğlu, S. (2012). Sağlık-Sağlık Hizmetleri ve Türk Sağlık Sistemleri, M. Tatar (Eds.), Sağllk Kurumları Yönetimi-I içinde. Eskişehir: Anadolu Üniversitesi Yayınları.

Stern, B. B. (1994). A Revised Communication Model for Advertising: Multiple Dimensions of the Source, the Message, and the Recipient. Journal of Advertising, 23 (2): 5-15.

Tengilimoğlu, D., Işık, O. ve Akbolat, M. (2017). Sağllk İşletmeleri Yönetimi, 8. Baskı. Ankara: Nobel Akademik Yayıncilık.

Usta, H. ve Tengilimoğlu, D. (2000). Advertisement in Healthcare and A Case Study on Patients' Opinions Towards Healthcare Advertisement. $1^{\text {st }}$ National Health Administration Congress, 20-21 May 2000, Hacettepe University, Ankara.

Wangenheim, F. V. (2005). Post Switching Negative Word of Mouth. Journal of Service Research, 8 (1): 67-78.

WHO (2001). European Health Report. Regional Office for Europe.

Yılmaz, E. (2011). Sağlık Hizmetlerinde Ağızdan Ağıza Pazarlama. Marmara Sosyal Araştırmalar Dergisi, (1): 1-18. 